
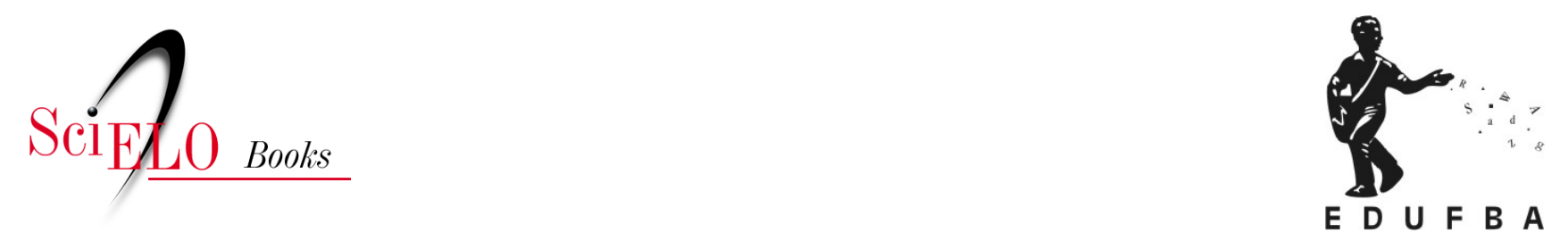

\title{
Capítulo 7 \\ Regulação afetiva do fluxo da experiência: a generalização do campo de sentimentos ligados à maternidade
}

\author{
Vívian Volkmer Pontes
}

PONTES, V.V. Regulação afetiva do fluxo da experiência: a generalização do campo de sentimentos ligados à maternidade. In: Trajetórias interrompidas: perdas gestacionais, luto e reparação [online]. Salvador: EDUFBA, 2016, pp. 188-218. ISBN: 978-85-232-2009-9.

https://doi.org/10.7476/9788523220099.0009.

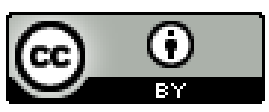

All the contents of this work, except where otherwise noted, is licensed under a Creative Commons Attribution 4.0 $\underline{\text { International license. }}$

Todo o conteúdo deste trabalho, exceto quando houver ressalva, é publicado sob a licença Creative Commons Atribição $\underline{4.0}$. 
Capítulo 7

Regulação afetiva do fluxo da experiência: a generalização do campo de sentimentos ligados à maternidade 


\title{
Narrativa autobiográfica da trajetória reprodutiva de Beatriz entre os contextos públicos e privados de saúde
}

\author{
É só a gente sentir aquele ser dentro da \\ gente... fiquei com vontade de sentir \\ isso de novo e ter nos meus braços vivo. \\ (Beatriz)
}

Beatriz possui história reprodutiva marcada por três perdas gestacionais, sendo um aborto espontâneo e dois bebês natimortos. No momento em que foram realizadas as entrevistas não estava grávida. ${ }^{7}$ A primeira gestação ocorreu em 2005, quando tinha 22 anos de idade e quatro anos de casada. Relata que o casal já planejava ter um filho, mas não para aquele momento, pois Beatriz considerava-se ainda muito jovem. Deste modo, a gravidez configurou-se, de algum modo, um evento inesperado. Apesar disso, relata que descobrir-se grávida foi um acontecimento considerado positivo: "pra mim foi muito bom [risos], principalmente descobrir que era uma menina... porque o meu maior sonho é uma menina [risos], pra gente foi muito bom, foi muito feliz... eu não esperava tanto naquele momento, mas

7 Beatriz foi entrevistada em dois momentos distintos. A primeira entrevista foi realizada em novembro de 2010, quando estava iniciando a investigação e tratamento imunológico, em decorrência das perdas gestacionais, na clínica privada. Embora estivesse acompanhada pelo marido, narrou sua trajetória reprodutiva praticamente sozinha. A segunda entrevista ocorreu quase um ano depois, quando ela voltou a me procurar para falar sobre a dificuldade para engravidar. Desta vez, estava sozinha. Solicitei, então, que contasse novamente sua história reprodutiva. 
eu gostei muito...". Além da questão da idade, Beatriz relata que se preocupava com o momento do parto, por tratar-se de um evento no qual as pessoas dizem que provoca intensa dor física, bem como com a sua capacidade para cuidar de uma criança, devido à percepção de imaturidade relacionada à sua pouca idade:

Acho que toda mulher antes de engravidar, tem medo do parto, e eu tinha muito medo [risos] e também eu queria amadurecer mais... Eu não me achava muito responsável [risos],... pelo fato de eu ser mais nova, sei lá, eu não sei explicar direito, mas eu acho que eu não 'tava' preparada naquele momento, antes, 'né', naquele momento.

Apesar dos receios, a gravidez transcorria sem complicações. Porém, ao completar cerca de sete meses, sua pressão arterial começou a elevar-se e outros sintomas apareceram, como edemas generalizados no corpo, dores no estômago e nas costas. Também foi constatado que o bebê em gestação estava perdendo peso. Tais sintomas pareciam configurar um quadro de eclâmpsia. Entretanto, a fim de realizar exames laboratoriais que confirmassem ou não tal diagnóstico, Beatriz precisou recorrer ao serviço de saúde público de outra cidade próxima - na medida em que morava em uma cidade pequena no interior da Bahia, que não dispunha desse serviço. Durante a espera pelo resultado dos exames - cerca de uma semana -, os sintomas persistiram.

Beatriz relata que compreendia o que representava a eclâmpsia, devido à experiência prévia de uma tia que teve esse diagnóstico durante a gravidez, resultando no óbito do bebê. Em detrimento a essa informação, preferiu acreditar na sabedoria popular, transmitida pela avó, que dizia: "a mulher quando está grávida e incha muito, dizem que vai ter um parto bom”. Além disso, a experiência corporal de sentir o bebê mexendo consistiu para Beatriz no indício de não havia nenhum problema com o bebê: "então, já que o bebê está mexendo bem, ele mexia muito, 'Ah, então bebê que mexe é um bebê saudável', aí eu fiquei despreocupada”. Porém, ao realizar um exame de ultrassonografia, quando já estava com 30 semanas de gestação, foi constatado que os batimentos cardíacos do bebê haviam parado - evento que foi percebido como "uma morte inesperada": 
Quando chegou o dia de eu fazer o pré-natal, eu fui e o médico não ouviu mais os batimentos, aí foi aquele choque pra gente, porque a gente tinha tudo prontinho, quarto todo pronto, até hoje eu tenho meu jogo de quarto todo prontinho [risos], aí eu descobri que não, não viria mais, mas... eu não tive medo na hora de pensar, já fiquei fazendo planos pra próxima gravidez [risos], em momento algum eu pensei em desistir, tive medo, sempre pensando positivo, tanto que engravidei, queria engravidar logo.

Conforme ilustra o fragmento acima, a narrativa de Beatriz sobre sua trajetória reprodutiva - marcada por perdas gestacionais e riscos à sua própria vida - foi acompanhada por uma expressão facial alegre e muitas vezes sorridente. Expressão afetiva aparentemente incompatível com o conteúdo do relato. Além disso, a experiência da primeira perda gestacional - uma ruptura significativa daquilo que era esperado acontecer parece não ter sido reconhecida e elaborada no âmbito afetivo, sendo automaticamente substituída pelo planejamento de uma próxima gravidez.

Assim, a partir do diagnóstico de óbito fetal e de uma pré-eclâmpsia grave, houve a necessidade de induzir o parto. Beatriz relata que chegou a ver a filha, mas não quis tocá-la devido ao medo que sentia de pessoas mortas:

Eu a vi quando ela... assim que nasceu, colocou pertinho de mim, não cheguei a tocar, assim, eu tenho pavor de pessoas que morrem... quando eu vi o bebê eu não consegui segurar, eu senti assim, não sei direito explicar, mas eu não consegui segurar... colocou no meu lado, eu ainda cheguei a tocar na mãozinha, mas pegar no colo e tudo eu não consegui.

O bebê natimorto foi sepultado pelo esposo e alguns parentes próximos. Beatriz não participou da cerimônia: "o sepultamento, isso, fizemos tudo isso, mas ela era muito bonita assim, parecia que 'tava' dormindo, foi até difícil pra gente acreditar..., porque foi tudo muito rápido, foi tudo bem... aconteceu rapidamente".

Para Beatriz, a primeira perda gestacional foi o resultado de uma assistência à saúde deficiente - que ela relaciona ao fato de ter sido realizada na rede pública - e da passividade do casal diante dos acontecimentos: 
Por causa da cidade, cidade pequena, não tem, só tem a rede pública e péssima também... e pelo fato da primeira gravidez ter tido aquelas complicações, eu acho que a gente se acomodou um pouco, e também a gente ficou muito confiante, assim, a gente como, ele é evangélico, a gente pensava muito, 'Deus vai me ajudar, vai dar tudo certo', os médicos também nos falavam, 'né', 'não, vai dar tudo certo', então, a gente confiou muito.

Seguindo a recomendação médica, Beatriz voltou a engravidar novamente um ano depois: "em momento algum eu pensei em desistir... antes era mais a rede pública, a partir da segunda gravidez, eu já parti para um médico particular, que eu já percebi que era uma gravidez mais arriscada". A segunda gravidez foi precocemente interrompida pela ocorrência de um aborto espontâneo quando estava com aproximadamente seis semanas de gestação. Tratava-se de uma gravidez anembrionada. ${ }^{8}$ Na medida em que o feto ficou retido em seu útero, precisou submeter-se ao procedimento da curetagem uterina: "eu fiquei assim..., eu saí meio desolada, eu fiquei sem chão, só em pensar de novo passar por tudo isso...”. Após essa segunda perda gestacional, o casal começou a pagar um plano de saúde para Beatriz, a fim de que ela pudesse ter acesso a uma assistência na qual eles acreditavam ter melhor "qualidade": "como já aconteceu isso, vamos procurar um médico particular e mais experiente, 'né', nessa área".

Em 2008, Beatriz engravidou pela terceira vez. Realizou o acompanhamento pré-natal no contexto da assistência privada, em uma cidade próxima da qual reside. Relata que a cada 20 dias ia para essa cidade realizar os exames médicos. No entanto, quando estava com cerca de sete meses, algumas alterações na gravidez foram detectadas pelo médico: "quando chegou o período de fazer a ultrassom morfológica, eu cheguei lá e o médico percebeu que o bebê estava muito abaixo do peso, a minha pressão estava muito alta, então ele percebeu que 'tava' alguma coisa errada". Beatriz foi encaminhada com urgência para uma clínica particular de outra cida-

8 Gestação anembrionada caracteriza-se pela ausência da imagem na ultrassonografia transvaginal da vesícula vitelina em saco gestacional igual ou superior a $10 \mathrm{~mm}$ de diâmetro médio ou a ausência de vesícula vitelina e embrião em saco gestacional com diâmetro igual ou superior a $16 \mathrm{~mm}$. (Rios et al., 2010) 
de, Feira de Santana, a fim de repetir o exame de ultrassom, em um equipamento mais moderno. Apesar de as informações médicas acerca das complicações gestacionais, Beatriz relata que havia levado um DVD para que fossem gravadas as imagens do bebê - que, mais uma vez, tratava-se de uma menina -, mas foi desaconselhada pelo médico que relatou que não seria possível ver o bebê, pois ele estava muito pequeno: "aí ele me disse: "não vai dar pra você ver nada, não vou nem te explicar, porque você não vai entender nada'". No outro dia, Beatriz foi internada em um hospital público com o diagnóstico de eclâmpsia grave, sentindo fortes dores no estômago e nas costas.

Apesar da percepção de risco à própria vida, Beatriz enfatiza na sua narrativa que, naquele momento, só pensava no bebê e na pequena chance dele sobreviver:

Eu mesma não pensava muito em mim, eu pensava no bebê, eu perguntava: “E ela quanta chance tem de vida?”... Mas eu já entrei no hospital já pensando muito, só pensava no bebê, só queria saber quanta chance ela tinha, né, eu acho que eu esqueci de mim nesse momento [risos].

Na medida em que o bebê ainda estava vivo, houve a tentativa, por parte da equipe médica que a acompanhava, de prolongar a gestação uma vez que haviam conseguido estabilizar a sua pressão arterial:

Então aí eu fiquei confiante, 'né', que iria dar certo. Isso foi na quinta ou na sexta, se eu não me engano, eu sentia o bebê mexendo e tudo, já no sábado para o domingo, eu não senti, eu senti parecido com o da última vez, aquele bolinho na barriga... na terça-feira, eu fiz um ultrassom, aí já confirmou que ela estava morta, então foi um choque muito grande pra mim, porque eu não tava esperando, eu tinha ainda esperança... tinha esperança de que pudesse acontecer um milagre.

Assim, após alguns dias de internamento, foi diagnosticado o óbito do bebê. Beatriz, então, precisou submeter-se novamente a um parto induzido. A interrupção da gravidez foi percebida como um evento inesperado e repentino: “tudo foi tão rápido que 'acontece' comigo, minha preocupação é essa, acontece tudo muito rápido, eu 'tou' normal, como eu 'tou' conversando com você aqui, mas quando eu chego no médico, ele já percebe 
que não 'tá' tudo bem". Na medida em que o bebê natimorto era muito pequeno, Beatriz retornou à sua cidade, após I5 dias internada, levando-o dentro de um recipiente com formol, sendo enterrado pelo marido, junto com o bebê perdido da primeira gestação.

A partir da experiência dessa perda gestacional, em diálogo com os profissionais de saúde, Beatriz construiu o significado de risco à sua própria vida:

Corri muito risco, porque eu tive HELLP. ${ }^{9}$ HELLP é... corre risco nos rins, de entrar em coma, pela pressão que aumenta... eu corri risco, né, eu corri mais risco de vida... foi bem mais grave, me disseram que foi bem mais grave do que a da primeira.

Após internamento hospitalar, Beatriz relata ter dado início a um novo planejamento para a próxima gestação: “cheguei em casa, lá eu já ficava fazendo os meus planos, de como seria a próxima gravidez". Combinou com o marido sobre acumular recursos financeiros até ter dinheiro suficiente para ter acesso a um atendimento médico especializado, oferecido pela rede privada de assistência à saúde:

[preparando-se] principalmente financeiramente, 'né', porque eu acho assim psicologicamente eu sempre tive, 'né', preparada [risos] porque eu sempre pensei positivo, não pensei em desistir nunca, sempre forte, 'né', assim, sempre pensando positivo.

9 Entre os distúrbios hipertensivos na gestação, há a pré-eclâmpsia, definida por uma pressão arterial elevada associada à proteinúria, ao edema, ou a ambos após vinte semanas de gestação. A pré-eclâmpsia pode ser leve ou grave. O tratamento definitivo para a préeclâmpsia ou a eclâmpsia é o parto. A urgência do mesmo depende da gravidade do caso. No caso de pré-eclâmpsia grave, a segurança da gestante deve ser considerada em primeiro lugar. A prioridade é avaliar e estabilizar a condição materna, particularmente as anomalias de coagulação. A síndrome HELLP que consiste de emólise, elevação de enzimas hepáticas e plaquetas baixas é uma forma de pré-eclâmpsia grave. O manejo é o mesmo da préeclâmpsia grave, ou seja, realizar o parto. A síndrome HELLP está associada a um mau desfecho materno e perinatal. A mortalidade fetal perinatal relatada na literatura médica vai de 7,7 a $60,0 \%$ e a maternidade materna de zero a $24 \%$. A morbidade materna é comum. Muitas pacientes com síndrome de HELLP necessitam de transfusão de sangue e de componentes sanguíneos e têm risco aumentado de insuficiência renal aguda, de edema pulmonar, de ascite, de edema cerebral e de ruptura hepática. (Reddy \& Witter, 2001) 
Então, com o objetivo de economizar dinheiro para realizar o tratamento médico, Beatriz passou a juntar moedas. Ao final de dois anos, relata que havia reunido mais de 20 quilos em moedas de um real, somando a quantia de aproximadamente sete mil reais. Assim, concluiu que havia chegado o momento de realizar o tratamento e, então, tentar uma nova gravidez.

Deste modo, buscou atendimento médico especializado após dois anos da terceira perda gestacional. Ao realizar os exames solicitados pelo médico especialista, foram identificadas algumas alterações imunológicas, tais como: trombofilias (alteração na coagulação sanguínea, havendo maior risco para a formação de trombos ou trombose) e fatores aloimunes (resposta imunológica do corpo materno de não reconhecimento e aceitação do concepto). Realizou o tratamento aloimune e foi liberada pelo médico para engravidar em dezembro de 2010 . Porém, quase um ano depois, Beatriz relata que ainda não havia conseguido engravidar. Por esta razão, solicitou atendimento psicológico em novembro de 2011 (momento em que a segunda entrevista foi realizada), por acreditar que a razão para não estar conseguindo engravidar consistia no elevado nível de ansiedade. Vale ressaltar que esse significado foi coconstruído com profissionais de saúde e outras pessoas da sua rede social próxima: “eu ainda não consegui engravidar, aí eu 'tô' achando, os médicos falam que é a ansiedade... eu preciso de uma psicóloga hoje, tenho que conversar, tenho que desabafar e tudo".

\section{As dinâmicas no âmbito do self: processos dialógicos envolvidos na autorregulação semiótica}

A trajetória reprodutiva de Beatriz apresenta-se marcada por perdas gestacionais e sérios riscos à própria vida, em decorrência da persistência em engravidar. Nesse cenário, no qual a vida é constantemente ameaçada ou perdida, muitas pessoas significativas expressaram oposição à escolha de Beatriz em persistir por esse caminho. Essas vozes em oposição 
à sua escolha pela maternidade biológica intensificaram a ambivalência relacionada à tomada de decisão entre engravidar novamente ou desistir.

Em detrimento a essa oposição e com o propósito de empoderar seu próprio selfe dar sustentação à decisão de engravidar novamente, Beatriz recorre a um poderoso aliado: o discurso biomédico. Afinal, tal discurso legitima o caminho escolhido - calcado especialmente no avanço tecnológico -, prometendo-lhe algumas certezas em um cenário repleto de incertezas:

A gente conversou com o médico, se ele falar que não tinha como, aí tudo bem, mas aí quando o pessoal fala na rua que a gente não pode, quem vai dizer é o especialista, 'né'? Ele disse não, vocês podem engravidar com o tratamento... porque as pessoas na rua falam muito, 'né', enchem muito a cabeça da gente, eu falei: 'Não, vou pensar, vou primeiro ao médico saber o que ele vai me dizer, se eu tenho chance ou não de engravidar novamente', então, graças a Deus, ele disse o que eu queria ouvir [risos].

A oposição de pessoas significativas à persistência de Beatriz em engravidar intensificou-se após a terceira perda gestacional - especialmente em decorrência às sérias complicações em seu estado de saúde. Nesse momento, até o esposo - que sempre ofereceu um importante suporte emocional para Beatriz, bem como um incentivo para que continuasse a engravidar -, também se mostrou contrário a uma nova gestação. A sua voz ecoa para Beatriz como uma tentativa de ampliar o campo de possibilidades futuras para a realização de outras trajetórias, como a trajetória alternativa de adotar uma criança ou mesmo de ser um casal sem filhos:

Quando eu cheguei em casa, ele: "Beatriz, você não vai engravidar de novo, pra você correr risco, eu não quero, vamos viver nós dois sozinhos, não quero que você corra risco mais". Porque ele pensou primeiramente em mim, aí eu falei 'Não, eu quero tentar novamente, se o médico disse que eu tenho chance, então eu vou tentar', 'Então, você que sabe, por mim viveríamos os dois sozinhos, se você quisesse adotar eu adotaria', mas eu falei 'Não, vou tentar primeiro, vamos dizer assim, não uma última vez, mas vamos tentar de novo"... 'Se tem tratamento, então, vamos tentar o tratamento'. 
As vozes de outros importantes membros familiares fizeram-se também presentes como uma tentativa de dissuadir Beatriz do propósito de continuar engravidando. Uma dessas vozes apresenta destaque em sua narrativa: uma prima do marido que considerava como se fosse sua irmã. Essa prima possui nível universitário e utilizou-se do recurso da internet para pesquisar sobre o que havia ocorrido na última gestação de Beatriz. Munida de informações sobre a gravidade dos eventos ocorridos (eclâmpsia grave, síndrome de HELLP), recorre à estratégia semiótica de enfatizar o pior do que poderia ter acontecido no passado - isto é, insuficiência renal, edema cerebral e, em consequência, entrar em estado de coma - alertando para a possibilidade de esses eventos acontecerem no futuro, caso Beatriz persista - no momento presente - em seguir por esse caminho. Nesse sentido, realiza a tentativa de desestabilizar a amarração semiótica construída por Beatriz - que utiliza signos provenientes da esfera médica para minimizar a ambivalência e reduzir o grau de incerteza frente ao futuro. E assim, questiona o poder e a promessa de certeza atribuídos ao discurso biomédico. Porém, o poder afetivo da sua voz não se mostrou hierarquicamente superior para dominar a voz do médico especialista:

A prima de Alberto [marido] também, ela até fala comigo que ela não é muito de acordo 'a' eu engravidar de novo... ela se preocupa muito comigo, ela é prima dele, mas tem aquela amizade que parece que é minha irmã... Então ela pesquisou muito, ela se preocupava muito comigo... ela me falou que eu corri muito risco, 'Você correu os riscos dos rins pararem, pelo fato da pressão ta aumentando muito', ela me explicou assim, por alto, mais ou menos o que ela pesquisou, e 'de entrar em coma, porque a sua pressão aumentava muito e poderia entrar em coma a qualquer momento'... então ela me falava 'tudo bem que o médico falou que você pode fazer, tentar novamente, com tratamento', mas ela sempre me fala 'médico nenhum dá 100\%', eu falei 'Não, mas eu acho que eles tem o fundamento deles e tudo, então eles não vão me enganar com uma coisa que eu possa correr risco mais tarde, então se ele ta falando que eu posso, ta me dando essa garantia, tentar, porque eu acho que se eu fosse correr risco de vida, ele não iria adiante no meu tratamento", "né'? 
Só que aí eu explico, eu falo "não, o médico já me disse que não vai acontecer tudo o que aconteceu da outra vez e se caso acontecer não vai ser tão forte, não vou correr tanto risco, porque eles estão próximos e vão interferir assim, para que não aconteça nada de grave, nem comigo, nem com o bebê".

A construção de signos fortes (Abbey \& Valsiner, 2004) - isto é, signos que estreitam demasiadamente o campo de significados, ao mesmo tempo em que fornecem o caminho mais claro para a pessoa seguir em um determinado momento - provenientes da esfera médica, tais como o signo genérico "tratamento", são internalizados de modo particular por Beatriz. Tais signos parecem sustentar seu movimento em direção à maternidade, na medida em que circunscreve o campo de possibilidades futuras, incluindo apenas determinadas trajetórias, como a do tornar-se mãe e ter um filho; enquanto exclui outras possibilidades, como a repetição de perdas e o risco à própria vida (ver Figura 13). Deste modo, esses signos permitem imaginar um futuro previsível, com a promessa de evitar ou reduzir danos em uma próxima tentativa de gravidez - reduzindo, assim, a ambivalência. A fabricação de distinções, através de mecanismos de atenção seletiva e da percepção, e sua organização semiótica trabalham no sentido de possibilitar a construção de um mundo subjetivo que pareça relativamente estável. (Valsiner, 2012) Porém, conforme apontam Abbey e Valsiner (2004), essa condição é de natureza enrijecedora do processo dialógico de construção de significados, negligenciando tão marcadamente a complexidade do fenômeno, e sendo funcional apenas temporariamente.

$\mathrm{Na}$ tentativa de construir um sentido de segurança, como se engravidar novamente constituísse uma trajetória cujo desfecho tornara-se previsível - graças ao tratamento médico especializado - um obstáculo importante fez-se presente: a "demora" em engravidar. O tempo decorrido das tentativas para engravidar, após tratamento imunológico com o médico especialista, e a sua não realização, aumentou a ambivalência de Beatriz entre o tentar ou não tentar engravidar novamente. A rede de apoio contribuiu para a ampliação da ambivalência, construindo o significado para a dificuldade de Beatriz engravidar relacionado à "vontade 
de Deus" (ver Figura 14). Aliando-se ao questionamento dos signos provenientes da esfera médica, houve a introdução nesse cenário de outro signo poderoso e hipergeneralizado, "Deus":

Aí ela me falando, 'né, essa prima dele, 'Olha, Beatriz, você tem tanta facilidade pra engravidar, por que que será que agora 'tá' demorando, será que não é Deus te mostrando que é pra você desistir e parar e tudo?'. Então, isso ficou muito na minha mente.

Figura 13 - Significados de gravidez: unidade de opostos e sua dinâmica de relações

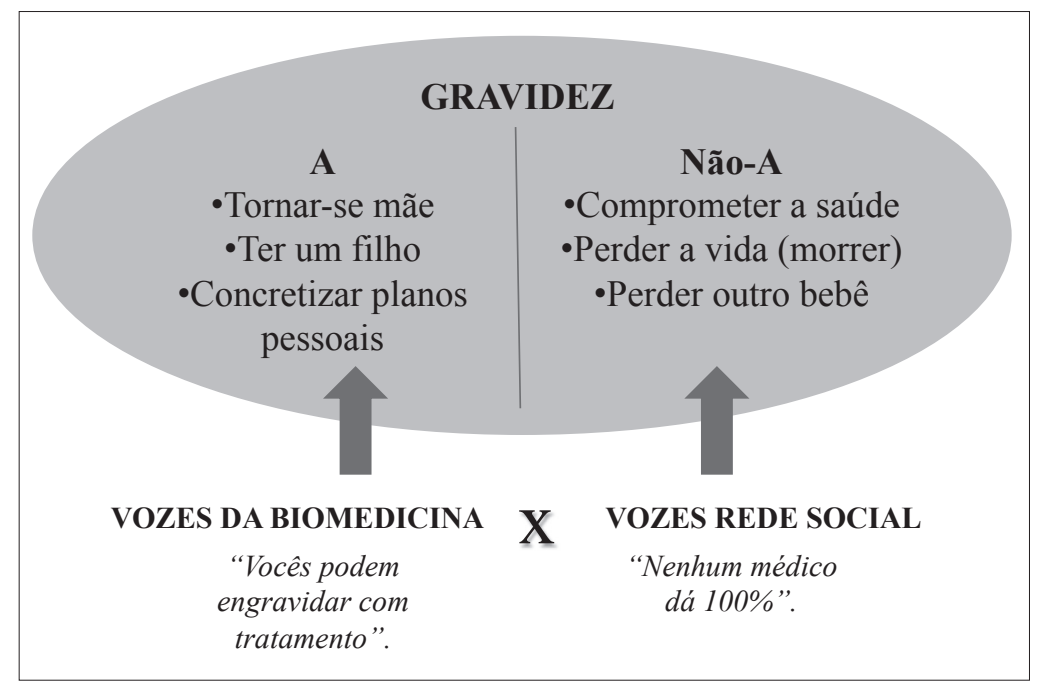

Fonte: elaboração da autora.

A internalização desse signo, através de um processo de construção ativa por meio da interação bidirecional com os outros sociais, levou Beatriz a um rezar reflexivo com um foco orientado para o futuro. Ou seja, levou-a a rezar com o propósito de refletir e dirigir ações futuras: voltar ou não a engravidar? Assim, estabeleceu com Deus uma comunicação, pedindo-lhe respostas sobre como deveria agir: 
Aí... quando eu cheguei em casa, eu conversei com Deus, eu falei: 'Oh, meu Deus, se for pra 'mim' desistir... se for pra eu poder desistir, então tira da minha mente, 'né', pra 'mim' poder esquecer e pronto'.

Vale ressaltar que, apesar da comunicação com Deus poder ser dirigida internamente e individualmente, ela também é indireta e ocorre sob a forma de metacomunicação. (Peskek, Kraus, \& Diriwachter, 2008; Valsiner, 2000) Essa metacomunicação depende da interpretação, isto é, do que alguém pode considerar serem mensagens de Deus e como essas mensagens serão analisadas e internalizadas. (Peskek, Kraus \& Diriwachter, 2008)

Figura 14 - Significados de gravidez: unidade de opostos e as mudanças na sua dinâmica de relações

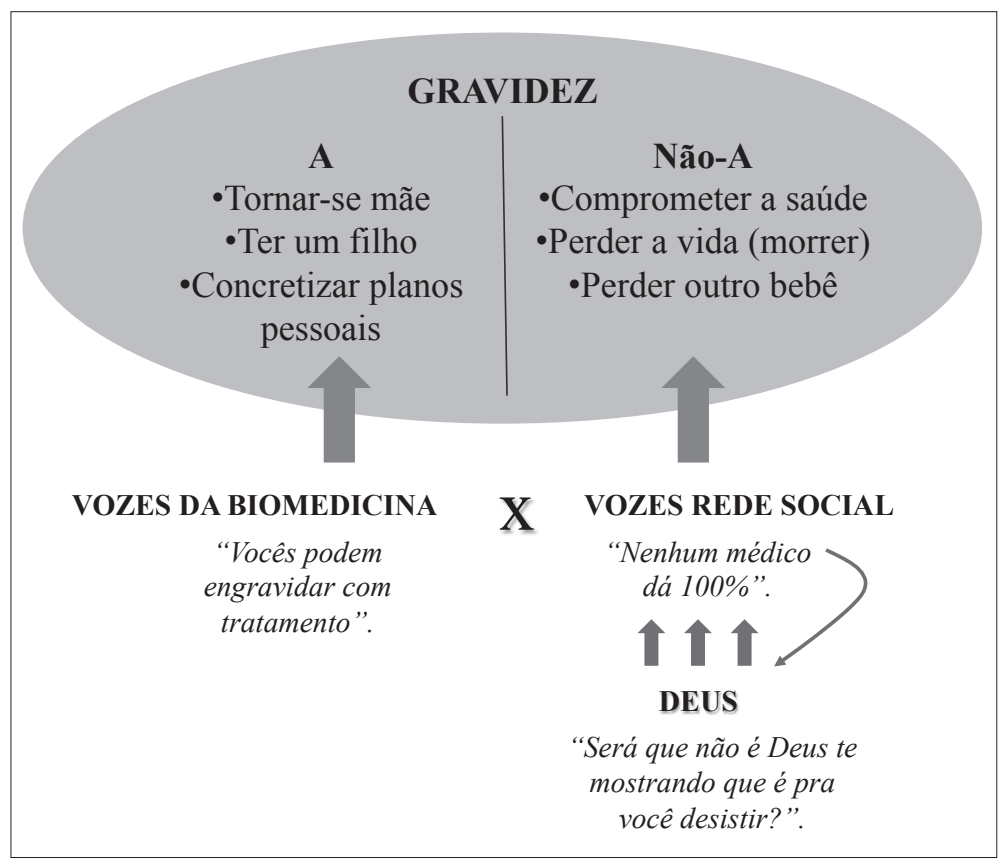

Fonte: elaboração da autora.

Diante da suposta condição de infertilidade, Beatriz recorreu à esfera médica a fim de construir algum significado que a explicasse. Porém, 
na medida em que não havia qualquer indício de problema físico em seu aparelho reprodutivo, houve a sugestão médica de que a dificuldade para engravidar poderia estar relacionada à ansiedade. A partir dessa sugestão, Beatriz empreendeu ações na tentativa de minimizá-la, envolvendo-se em outras atividades, como bordar e vender cosméticos.

No entanto, em certo momento, constatou que a questão da maternidade não lhe ocorria mais em seus pensamentos. Essa autorreflexão a levou a indagar se isso significava que a vontade de Deus era, então, que não engravidasse mais. Como se Deus estivesse respondendo ao seu pedido que, se fosse da vontade Dele a desistência da maternidade, que lhe permitisse simplesmente esquecer.

Deste modo, a ambivalência que havia sido minimizada com a construção do significado de "ansiedade" - a partir da sugestão médica -, volta a se intensificar, promovendo certa confusão em seus pensamentos. Nesse momento, então, há a construção de outros significados, como a ideia de estar sendo castigada por Deus:

Eu esqueci um pouco da gravidez, aí eu já fiquei pensando: 'Meu Deus, será que foi por que eu pedi pra 'mim' esquecer?'. E Deus já 'tava' me mostrando que não era pra 'mim' engravidar? Então começou aquela confusão na minha cabeça, 'Será que é pra 'mim' poder parar, que eu já esqueci?'... porque assim, eu, na mesma hora que eu pensava que não era pra 'mim' engravidar, já me questionava: 'O que foi que eu fiz, por que que Deus 'tá' me castigando por isso?', 'né', porque eu tenho tanta facilidade pra engravidar, tanto tempo tentando sem conseguir... aí ficava me questionando 'Por que? O que eu fiz de errado?', 'né', e voltando a pensar nisso, 'Será que Deus não quer que eu engravide? Será que é pra eu poder parar, pra desistir?' [risos], então isso me deixou muito confusa, eu fico sem saber direito o que é que eu faço.

A autorreflexão de Beatriz a respeito da "vontade de Deus" - suposta ser hierarquicamente superior a sua própria vontade - mostra-se ambígua, pois Beatriz parece não ter clareza acerca de qual direção esse signo poderoso parece indicar-lhe seguir. Afinal, por um lado há a dificuldade para engravidar e a constatação do período de tempo em que ficou sem pensar na questão da gravidez. Eventos que parecem indicar a vontade 
de Deus para que desista de seguir em direção à maternidade. Por outro lado, relata que o tratamento médico que vem realizando para engravidar sem riscos à sua vida ou a do bebê possui um custo muito elevado, o que a preocupa, pois não sabe até quando poderá pagar. Apesar disso, constrói o significado de que Deus está ajudando o casal a seguir com o tratamento: "mas graças a Deus, Deus está nos ajudando, por enquanto ainda continua tudo normal, eu acho que é bem provável que nós não iremos parar (o tratamento) por enquanto. [risos]. Mas eu estou mais confiante por isso".

A vontade de Beatriz de engravidar novamente, assim, parece persistir em seus planos futuros, à revelia da ambiguidade dos significados atribuídos à vontade divina ou às vozes de outros significativos contrários a essa decisão. E esse movimento persistente de "nadar contra a maré" - reduzindo a ambivalência e as incertezas relacionadas ao futuro - é amparado na suposta "certeza" e previsibilidade "vendida" - por um elevado custo - pelo discurso biomédico:

Olha, em desistir, eu desistiria pela situação financeira, não por, porque pra tentar engravidar, eu acho que nunca, só se o médico chegar para mim e falar "Você não pode, de jeito nenhum, se você engravidar, você corre risco e pode morrer" então, aí eu pararia... mas nenhum médico nunca me disse isso. Sempre me diz que eu tenho chance de engravidar, sim, com tratamento, porque, Dr. M. me disse, 'Sem o tratamento, sim, você corre riscos, agora com o tratamento, não, com o tratamento, se você fizer tudo direitinho, você não corre risco nenhum', então eu fico muito confiante, assim, pra desistir eu acho que eu não desisto fácil, não [risos].

Deste modo, alguns signos foram internalizados por Beatriz, advindos da esfera médica - a partir de pesquisas realizadas na internet, de consultas com o médico especialista e relatórios médicos - e que permitiram a redução da ambivalência em relação à incerteza diante do futuro. Tais signos, como a ideia de "trombose placentária", "incompatibilidade sanguínea", "tecnologia avançada" e "tratamento", possibilitaram a construção de algum sentido para as perdas anteriores (rupturas inesperadas nas trajetórias do passado), bem como a construção imaginária de estabilidade, de certo controle e segurança, dirigida para o futuro: 
Já li muito, já pesquisei na Internet, vi vários casos, e graças a Deus, 'né', que a tecnologia está tão avançada que possa nos dar essa oportunidade, 'né', de tentar novamente... pelo que eu pude entender assim dos relatórios que eu tive dos problemas, como eu tive trombose placentária, 'né', e a incompatibilidade... o nosso sangue não é compatível pelo fato de sermos do mesmo tipo, O positivo, mas tem alguns componentes que não combinam, então eu acho que isso que leva ao meu corpo rejeitar, o médico me explicou que o meu corpo rejeita, aceita como um corpo estranho e quer expulsar. Acho que por isso eu tinha aquelas complicações e tudo e também a trombose placentária... e pelo fato também do sangue 'tá preso ali, 'né, tende a minha pressão aumentar, porque 'tá' preso, ele não circula normal, isso o médico me explicou também.

Conforme Valsiner (2012), cada interpretação é carregada de valor e prescritiva quanto à ação. E assim, as informações médicas - internalizadas de forma particular por Beatriz - circunscrevem a gama de possibilidades futuras, influenciando o momento presente, na medida em que empoderam Beatriz para a tomada de decisão e subsequente ação. Ação esta, relacionada ao voltar a engravidar, após realizar tratamento médico (ver Figuras 15 e 16).

Figura 15 - Gama de trajetórias futuras possíveis

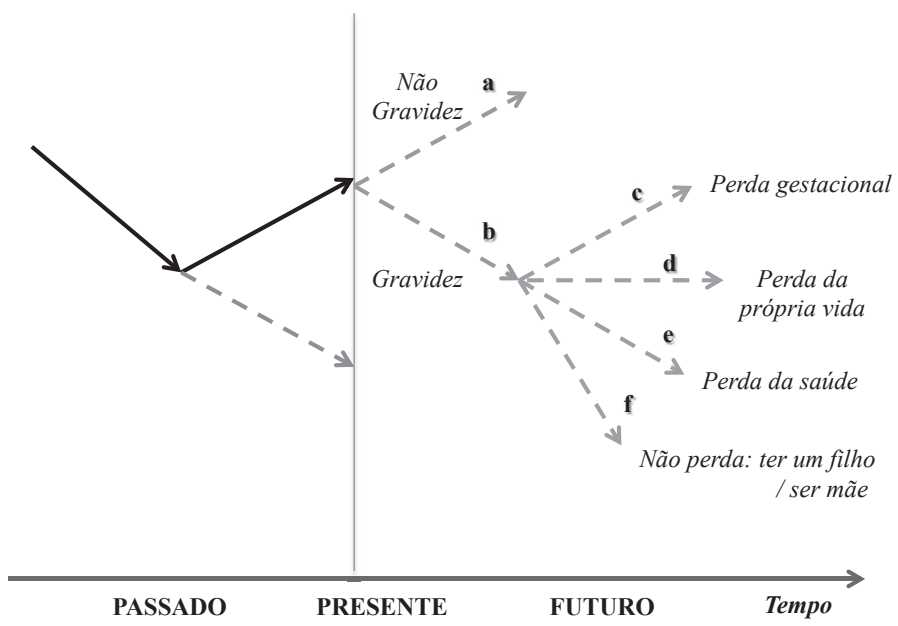

Fonte: elaboração da autora. 
Figura 16 - Trajetórias futuras circunscritas por signos provenientes da esfera médica

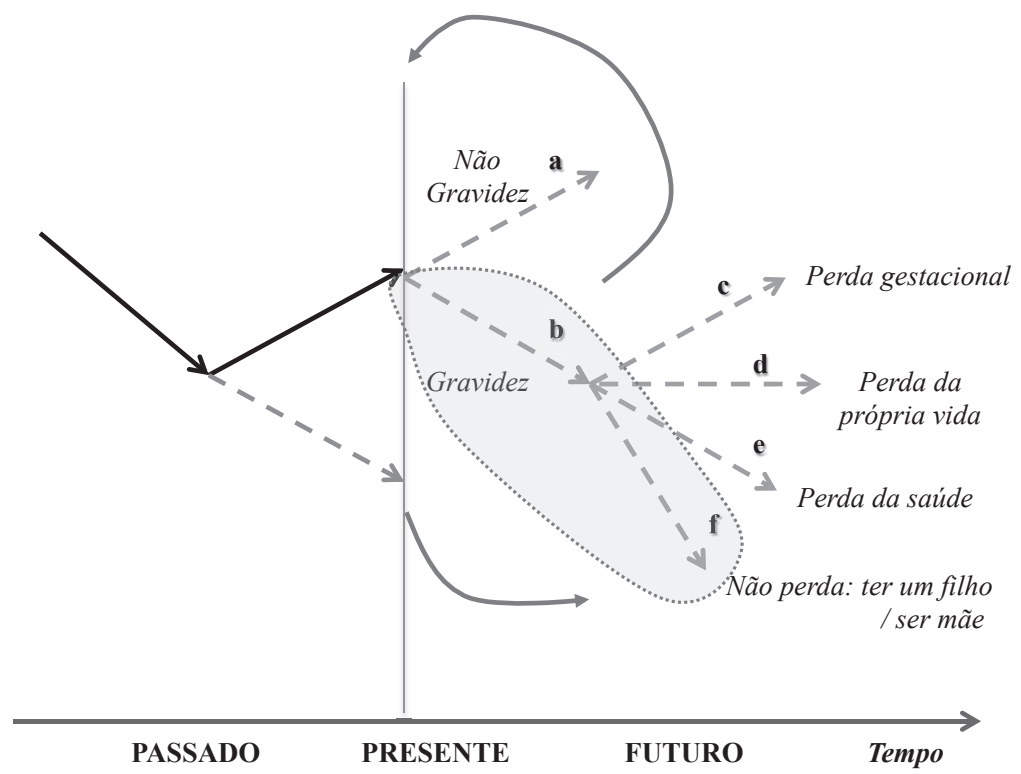

Fonte: elaboração da autora.

\section{Mediação semiótica e estratégias para a construção de continuidade: o luto não realizado}

O processo de construção de significados se desenvolve a partir da necessidade de pré-adaptação às condições ambientais futuras - que, no momento presente, ainda não são conhecidas. O papel dos outros sociais nesse processo, como o dos médicos e da rede social próxima, é aquele de orientação do processo de microgênese. Os significados, deste modo, são construídos em movimento. Outro aspecto fundamental desse movimento de construção de significados consiste nos processos afetivos. Afinal, a regulação e organização dos significados é uma função desses processos. O afeto é a base sobre a qual os organizadores semióticos se estabelecem e configuram. (Cabell \& Valsiner, 2011)

A experiência subjetiva é sempre construída sobre uma relação afetiva com o mundo. As pessoas criam sentido para suas relações com o 
mundo, e para o próprio mundo, através de seus sentimentos - que são culturalmente organizados por meio da criação e uso de signos. (Valsiner, 2012) Esta relação afetiva com o mundo se constitui como uma totalidade - uma combinação do passado, presente e futuro sentidos simultaneamente como um. (Cabell \& Valsiner, 2011) O domínio dos sentimentos é central para a construção de culturas pessoais. (Valsiner, 2012) Deste modo, os processos afetivos humanos estão intimamente ligados aos significados que deles emergem. (Valsiner, 2012) Partindo desse pressuposto, pode-se analisar a relação entre processos afetivos e significados na trajetória de Beatriz. Ao longo da sua narrativa fizeram-se presentes alguns indícios de uma tentativa de minimizar ou negar a gravidade das complicações gestacionais experienciadas, bem como de substituir um bebê perdido por outro, o mais breve possível, colocando a sua própria vida em risco. Também sobressai o discurso repleto de risos, como se a história narrada fosse cômica, em vez de triste. Tais elementos parecem indicar um processo de luto não realizado ou o não reconhecimento afetivo dos riscos e das perdas experienciadas. O relato a seguir ilustra a tentativa de negar ou minimizar os riscos à gestação e à própria vida, a partir da construção de significados para uma situação de imaginária normalidade:

Eu fiquei em casa aguardando chegar os exames, mas aí começava, 'né, pressão alta, o inchaço persistia, dor de cabeça e tudo, mas assim, só mais esses sintomas, e a gente ouvindo conversas de idosos, minha vó que antigamente falava, a mulher quando 'tá' grávida e incha muito, dizem que vai ter um parto bom, só que hoje em dia não tem mais isso, 'né', aí, sei lá, acho que pensava muito nessa parte, e também eu não sentia nada além disso. Então, já que o bebê está mexendo bem, ele mexia muito, "Ah, então bebê que mexe é um bebê saudável", aí eu fiquei despreocupada, mas quando chegou o dia de eu fazer o pré-natal, eu fui e o médico não ouviu mais os batimentos, aí foi aquele choque pra gente, porque a gente tinha tudo prontinho, quarto todo pronto.

As intercorrências em uma gestação consistem em uma situação crítica que exige a construção de algum significado generalizado que, de algum modo, reduza a ambivalência diante dos acontecimentos, promo- 
vendo algum tipo de ação. No exemplo descrito acima, Beatriz parece negar a possibilidade de que os sintomas que sente representem alguma complicação gestacional importante, mas, ao contrário, recorre à bricolagem de alguns significados a fim de amenizar a gravidade da situação. Assim, integra em sua narrativa os ditos de sua avó - resgatados de um diferente contexto e momento histórico -, cuja crença explicava que o inchaço na gravidez era um indício de um bom parto. Relacionado a esse significado está à crença médico-popular de que bebê em movimento no útero materno é um bebê saudável. Com esse mosaico de diferentes representações, Beatriz consegue reduzir a ambivalência intrapsicológica, argumentando para si mesma que tudo estava bem. Porém, não consegue mudar o rumo dos acontecimentos, cujos sintomas, na verdade, compunham um diagnóstico de pré-eclâmpsia, que culminaram na morte do bebê no último trimestre de gestação e coloram em risco a sua própria vida - acontecimentos estes tomados como surpresa por Beatriz, que, contrariamente, esperava o nascimento de um bebê saudável, a partir de um parto tranquilo.

Seguindo nessa direção, também chama a atenção a narrativa construída sobre a primeira experiência de perda gestacional - que remete à lembrança da sua filha morta -, e sua reação emocional, isto é, o riso. Tal reação parece incompatível com o conteúdo abordado no relato, pelo menos quando contextualizamos esse discurso dentro da nossa cultura, que relaciona a morte à tristeza. A história contada parece desprovida de emoção, o que pode sugerir que Beatriz ainda não tenha se defrontado com a perda que teve, a qual não é possível substituir: "Da primeira [gravidez] eu vi, eu vi o bebê, 'tava' perfeito, parecia até que tava dormindo, muito bonitinha [risos]".

Beatriz relata sentimentos de "tranquilidade" no momento em que foi constatada a morte do bebê, bem como durante o parto, refletindo certa inadequação desta reação emocional para com a situação: "me surpreendi comigo mesma". Além disso, relata que sua percepção, ao ver o bebê morto, foi a de considerá-lo como se estivesse vivo, "dormindo". Também refere que, após a perda, localizou o bebê perdido em outro 
bebê (filho de uma vizinha), que considerou muito parecido com a filha perdida. Todos esses aspectos parecem revelar não só uma notável ausência de pesar, como também de um não reconhecimento afetivo da perda, como ilustram os relatos que se seguem:

Olha, eu me surpreendi até comigo mesma, porque eu fiquei até muito tranquila, muitos, também médicas, enfermeiras 'achou' que pelo fato de eu 'tá' na minha primeira gravidez, você passar por esses problemas todo, eu fiquei muito tranquila, passei pelo parto, tudo, foi assim uma situação que eu fiquei muito tranquila, nem parecia que tava acontecendo isso tudo comigo.

Até um tempo atrás, eu, por incrível que pareça, tinha uma vizinha minha, que assim que a menina chegou no dia seguinte, na semana seguinte, que... quando ela entrou, se fechasse os olhos era o mesmo que eu tivesse vendo o meu bebê, muito parecido, ai fiquei com aquilo na mente, 'né', aquela fisionomia dela... se parecia com essa menina, sempre que eu via essa menina me lembrava.

Outro aspecto importante consiste na persistência em nomear o próximo filho - ao qual Beatriz espera que seja do sexo feminino - com o nome escolhido para o primeiro bebê perdido: "Ester seria o nome da minha filha, então de fato permanece, se eu tiver uma menina será uma Ester de novo. [risos]".

O caso Beatriz, assim, parece ilustrar uma situação na qual há a negação da morte. Há a negação da perda como algo irreparável, que não pôde ser evitada no passado, bem como não poderá ser reparada no futuro. Do mesmo modo, há a negação da possibilidade dessa perda voltar a se realizar no futuro, alicerçada principalmente pelo discurso biomédico e suas promessas de certeza, pautadas no avanço tecnológico.

Deste modo, Beatriz constrói o significado de que a perda é passível de ser recuperada, em um futuro próximo, caso o casal alcance algumas condições consideradas imprescindíveis, tais como: ser acompanhada pelos melhores médicos especialistas, cujos serviços privados - de elevado custo -, estejam inseridos no mercado de uma grande cidade. E assim, ao mesmo tempo em que experiencia no corpo, no momento presente, a morte de um bebê, seus pensamentos e sentimentos já estão 
projetados para o futuro, no planejamento de uma nova gravidez. Há a construção do significado de que é possível recuperar seu projeto inicial de vida, recuperar a sua filha Ester, sem conseguir dar-se conta que essa reparação é da ordem do impossível - dada a natureza do tempo que é irreversível.

Assim, analisando mais detidamente o processo de construção de significados empreendido por Beatriz, outros elementos precisam ser considerados. Afinal, Beatriz relata que a circunstância da morte lhe desperta afetos dos quais não consegue expressar exatamente em palavras: "não sei direito explicar". Porém, na construção narrativa realiza o esforço reflexivo, semioticamente ancorado, de circunscrever esse afeto negativo em termos de emoção, que denomina de "pavor": "tenho pavor de pessoas que morrem".

No que pese esse intenso afeto negativo relacionado à morte, as perdas gestacionais experienciadas ocorreram dentro do seu próprio corpo, sem que houvesse qualquer alternativa concreta - como a esquiva, por exemplo - de evitar deparar-se com algo que lhe desperta profunda aversão. Nesse momento, porém, certo mecanismo psicológico de autoproteção parece ser acionado. E Beatriz, então, realiza a tentativa de negar a morte, a perda já consolidada. E isto ocorre em termos afetivo-semióticos: age e sente como se o bebê não tivesse morrido ("parecia até que estava dormindo"), recusa-se a tocar em seu corpo gelado e abdica de participar do ritual fúnebre realizado pelo marido. A veracidade da morte é colocada em questão e compartilhada pelo marido, que ao ver a filha no caixão, reforçou a ideia da aparência viva do bebê:

Quando eu vi o bebê, eu não consegui segurar, eu senti assim, não sei direito explicar, mas eu não consegui segurar... colocou no meu lado, eu ainda cheguei a tocar na mãozinha, mas pegar no colo e tudo eu não consegui... eu não consegui nem chorar... aquele rostinho redondo e tudo... pelo fato de ter nascido logo muito perfeita, não parecia estar deformada, nem nada, então muito perfeita... [No enterro, quando o marido abre o caixão] ele falou que nem parecia que 'tava' morta, parecia que 'tava' dormindo, não 'tava' inchada, 'tava' muito bonita, ele falou que ela 'tava' perfeita, ele até ficou na dúvida: 'Será que realmente ela 'tá' morta ou não?'. 
Toda construção de significados envolve signos de natureza dual que consistem do núcleo A e seu contexto interdependente imediato não-A - formando um todo complexo. O não-A é a sua negação ou o seu oposto. (Cabell \& Valsiner, 2011; Valsiner, 2012) Assim, por exemplo, quando uma mulher engravida pode-se delinear a construção de significados em torno da vida (núcleo A), com sua contraparte não-A, a morte (ver Figura 17). A ocorrência de um aborto ou uma perda gestacional inverte essa dominância: a morte torna-se o núcleo desse complexo de significados, enquanto a vida a sua contraparte, o contexto.

Figura 17 - Complexo de significados na gravidez e perda gestacional

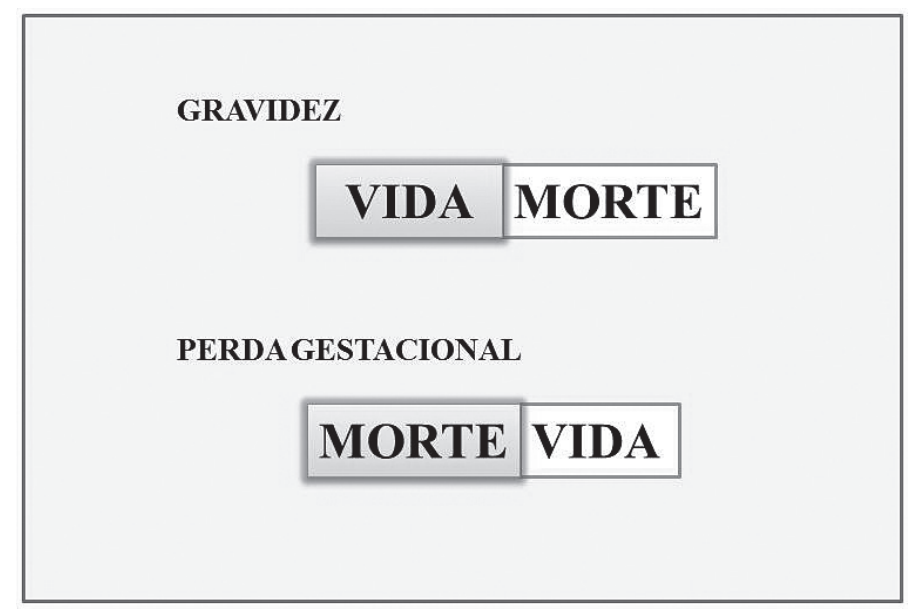

Fonte: elaboração da autora.

No caso analisado, um dos componentes do campo de construção de significados - a morte - aparece temporariamente em suspenso, enquanto que Beatriz esforça-se vigorosamente para que a vida se realize. Planeja minuciosamente a próxima gestação, pesquisando sobre o assunto na internet, informando-se a respeito do tratamento médico e do especialista que poderá recorrer, juntando, moeda por moeda, os recursos financeiros para concretizar seus planos. Porém, a condição de infertilidade, após sua terceira perda gestacional e tratamento médico 
especializado, precipita a crise que tanto buscou evitar: reconhecer a ocorrência da perda e a impossibilidade de sua reparação.

Assim, o processo de luto ou processo afetivo-semiótico de reparação da ruptura que até então não havia sido experienciado em sua plenitude - pelo não reconhecimento do caráter definitivo da perda - parece avançar, desencadeado por essa situação de crise. Nesse sentido, na segunda entrevista realizada com Beatriz, houve a expressão, em alguns momentos, de outro tipo de emoção - a tristeza - manifestada através do choro. Em um desses momentos, ela relatava sobre a reação da sua mãe com a perda do último bebê, refletindo sobre o papel materno que, para ela, relaciona-se à proteção do filho. Nesse instante, então, ela chora e faz referência às mudanças em seu modo de sentir, pensar e agir em decorrência do reconhecimento da perda irreversível:

Ela (a mãe) ficou também muito, muito triste, que ela sempre falava que ela queria passar por tudo, ela queria assim, se pudesse, sentir todas as dores do mundo só pra 'mim' não sentir [risos], então ela ficou assim, porque ela é daquele jeito de mãe muito protetora, que não quer que o filho 'sente' dor nenhuma, não sinta tristeza nenhuma, então ela... aí ela... posso falar, ééé.. [silêncio/chora]... desculpa [riso]... é, ultimamente 'tá' sendo difícil pra mim... porque assim, eu sempre, desde a primeira gravidez, 'né', como eu falei que eu chorei muito, e tudo, mas eu chegava em casa, meu marido, ele aparentemente parecia que sofria mais que eu, mas pra mim era como se a ficha não tivesse caído, a partir de um mês, um mês e pouco, eu sentia aquele vazio, aquela coisa toda, então aí eu percebia aquela perda que eu tinha, que eu tinha tido. O que aconteceu também na última gravidez, 'né', eu cheguei em casa depois não parecia aquela tristeza toda, mas com o tempo, depois que eu fui começar a sentir, e agora.

E ultimamente, assim, antes eu não me sentia tão sensível, tem momentos que eu me sinto, às vezes, eu choro por bobagem, alguma coisa assim, eu posso ouvir uma música, principalmente evangélica, 'né', às vezes dá aquele vazio, aquela perda, aquela sensação de perda, 'né', então, assim, sem mais nem menos eu começo a chorar. Já antes, eu não era desse jeito, eu até era muito forte, eu até me surpreendia, 'né', por tudo que eu passei e 'tá' tão forte assim, 'né', só que ultimamente, às vezes, a gente não aguenta [risos]. 
Entre as reações emocionais precipitadas pelo reconhecimento da perda destacam-se um elevado nível de ansiedade, crises de choro sem motivo aparente, irritabilidade, agitação, nervosismo e raiva - geralmente dirigida ao marido: "Eu fico tão irritada com ele, às vezes, eu falo coisas que não devia, às vezes sou ignorante às vezes com ele (o marido)... Então essa raiva veio sem mais, sem menos, porque ele não me fez nada... o problema todo está em minha cabeça". Conforme Parkes (1998), os traços mais característicos do processo de luto são episódios agudos de dor, com muita ansiedade e dor psíquica. Além disso, tanto a raiva quanto à irritabilidade estão relacionadas à fase inicial do luto. Vale ressaltar que foram esses os sintomas que levaram Beatriz a buscar um atendimento psicológico. Afinal, havia o significado coconstruído com profissionais de saúde de que tais sintomas - em especial a ansiedade - poderiam estar relacionados com a condição de infertilidade. Então, com o objetivo de aplacá-los, para que conseguisse engravidar novamente, Beatriz recorreu a um atendimento psicológico.

\section{Trajetórias não realizadas: sombras do passado no presente e futuro}

Conforme Valsiner (2012), as pessoas sentem prospectivamente. Ou seja, antecipam afetivamente o futuro, como um modo de ter algum controle, criar alguma estabilidade diante da imprevisibilidade do próximo e inédito instante da experiência. E é essa predição imaginativa e afetiva do futuro que orienta a pessoa no momento presente. "A experiência humana está constantemente dirigida para o futuro, numa pré-adaptação frente à incerteza desse futuro". (Valsiner, 2012, p. 258) O esforço humano em direção a esse desconhecido, criando novidade, é um aspecto inevitável do ser humano - "um ato de cruzar fronteiras". (Valsiner, 2012) Nesse processo de sentir à frente há uma coordenação com o passado de dois tipos: o que realmente aconteceu e o que poderia ter acontecido (mas não aconteceu). Do mesmo modo, há trajetórias possíveis no futuro: potencialidades e possibilidades. Logo, a perspectiva da psicologia cons- 
trutivista semiótico-cultural defende uma orientação do passado para o futuro. (Cabell \& Valsiner, 2011)

Em alguns momentos da sua narrativa, Beatriz retoma seletivamente o passado e, através da função semiótica da imaginação, reflete sobre o que poderia ter sido caso os bebês que morreram estivessem vivos. Estas trajetórias potenciais do passado, denominadas por Bastos (2012) como trajetórias sombra - apenas possíveis no momento presente através da imaginação -, a levam a refletir sobre um presente alternativo (no qual seria mãe de duas crianças). O contraste ou a tensão entre o presente real (o que é, ou seja, não ser mãe, não ter filhos) e o presente alternativo (o que poderia ter sido, ou seja, mãe de dois filhos) aparecem na narrativa projetados para o futuro: preocupa-se em recuperar o quanto antes aquilo que deveria ter, mas ainda não tem. Preocupa-se com a sua idade (antes tão jovem e no momento atual a percepção de estar ficando "velha") e essa tensão modifica o presente e a perspectiva de futuro, fazendo-a refletir sobre as trajetórias não realizadas:

Então eu vou tentar novamente pra ter logo a minha graça, porque eu fico assim muito ansiosa pelo fato de pensar, antigamente eu tinha os meus amigos que engravidaram junto comigo... que têm agora crianças mais ou menos na mesma idade [que] seria da primeira, cinco anos, aí só em pensar em ver elas com os filhos e eu por enquanto ainda sem nenhum, aí me dá mais ansiedade... Eu já estou me achando muito velha agora... na época em que eu engravidei pela primeira vez eu tinha 22 anos, agora eu tenho 28. Então eu penso, se eu tivesse um filho eu 'tava' com um filho de quase 6 anos... Eu vejo sempre as minhas amigas, eu tenho até uma amiga que engravidou na mesma faixa que eu, na primeira, ela já 'tá' com filho, a minha era menina, o dela menino, de 5 a 6 anos, a mesma faixa etária, a diferença é de meses, e ela depois engravidou, também, perto da que eu engravidei dessa última vez, então ela ta também com uma menina de quase dois anos. Então eu já fico, quando eu vejo ela, eu já fico, eu fico pensando: 'Olha, eu também já poderia estar com dois", então sempre quando eu vejo aquelas minhas amigas, aquelas crianças que nasceram na mesma época das minhas, que era para nascer, aí eu já fico naquele pensamento: 'Por que que eu também não estou com os meus agora?', então aí, as vezes já me preocupa um pouco. 
Deste modo, Beatriz seletivamente relembra o passado, combinando essas memórias com desejos imaginados e projetados para o futuro. Reconstrói o passado mudando simultaneamente a perspectiva de futuro e promovendo a emergência de um sentimento de urgência expresso em ansiedade - no momento presente, para realizar a trajetória da maternidade. Essa são as dualidades presentes em sua narrativa: a tensão entre o que é (presente real) e o que poderia ter sido (passado potencial/trajetória sombra), bem como entre o que é e o que ainda não é, mas pode vir a ser (futuro potencial imaginado). Tais dualidades orientam o seu desenvolvimento em direção à maternidade.

\section{O sagrado da maternidade: promotor dos modos de sentir, pensar e agir}

O mundo subjetivo das pessoas configura-se como uma "totalidade complexa da experiência imediata" que está constante e dinamicamente mudando. (Valsiner, 2012, p. 256) Assim, os processos semióticos que as pessoas introduzem nas próprias vidas são guiados no sentido de orientar e regular esse fluxo para alguma direção selecionada no futuro. (Valsiner, 2012) No caso de Beatriz, a direção selecionada no futuro é a maternidade - ela age e sente para o futuro, nessa direção.

Através da narrativa de Beatriz, pode-se notar que a maternidade consistia em uma meta futura que havia planejado concretizar quando completasse 30 anos de idade. Deste modo, houve a construção de uma fronteira simbólica - estabelecida a partir do critério da faixa etária -, bem como dos significados "nova" (antes dos 30 anos) e "velha" (depois dos 30 anos) para tornar-se mãe. Porém, a primeira gravidez, não planejada, ocorreu quando tinha apenas 22 anos de idade, momento em que se considerava ainda muito jovem para ter um filho. Logo, ao engravidar, cruzou a fronteira dentro de sua própria cultura pessoal, para aquilo que havia planejado. Apesar da ocorrência do não planejado, a gravidez precoce foi afetivamente experienciada com certa alegria. Entretanto, a experiência involuntária de uma perda gestacional tardia 
- no último trimestre de gravidez - levou à emergência de um sentimento de urgência em relação à gravidez - destruindo a fronteira etária simbólica previamente construída. A emergência desse sentimento de urgência esteve principalmente relacionada com a sensação física dos movimentos fetais dentro do próprio corpo, mas também com a antecipação futura do contato com o bebê vivo e o reconhecimento de continuidade de algo seu (traços físicos) em uma nova geração, conforme ilustra o relato a seguir:

Aí eu quis de novo, porque só aquela sensação da gente sentir o bebê mexendo dentro da gente, a sensação de ter um bebê no colo, de saber que é nosso, ter as características nossas, aí eu falei 'Ah, não, não vou mais aguentar esperar tanto tempo, então se Deus me mandou antes do planejado, então eu vou tentar novamente pra ter logo a minha graça'.

Deste modo, a experiência corporal dos movimentos fetais permitiu a Beatriz sentir em seu próprio corpo a maternidade, sendo tomada por essa sensação, por esse signo hipergeneralizado - carregado de afeto. Como se o sagrado da maternidade - a potencialidade feminina de dar à luz, de criar a vida, como se fosse um semideus - a tivesse tomado, guiando seus pensamentos, sentimentos e condutas.

Considerando, porém, que a construção de significados envolve signos de natureza dual, o signo maternidade (núcleo A) precisa ser considerado juntamente com a não maternidade (não-A). Ou seja, ao mesmo tempo em que o signo maternidade remete ao significado de gerar a vida, também apreende o significado de gerar a morte - que desperta em Beatriz a emoção por ela denominado de "pavor". O sentimento associado com ambos (vida e morte) acontece em uma fronteira. Como parte da vida há a morte, ambos formando um todo complexo, ainda que, ao mesmo tempo, a morte seja o oposto da vida.

Deste modo, o sagrado da maternidade é um campo afetivo hipergeneralizado. Um sentimento devastador, intenso, sentido em suas entranhas com os movimentos fetais, que leva à emergência de um estado afetivo do tipo: "estou sentindo algo que eu não consigo especificar o que é". 
Eu acho que pela experiência, é só a gente sentir aquele ser dentro da gente, aquela movimentação, não sei, eu fiquei com vontade de sentir isso de novo e ter nos meus braços viva, 'né, depois de nascer e tudo, porque por essa parte eu ainda não passei [risos]. Eu já senti, eu gostei muito da sensação de ter o bebê mexendo e tudo, aquela coisa toda na gente, eu gostei muito. Aí falei não, 'tou' com saudade, eu quero agora tentar de novo, e ter um filho.

Conforme Valsiner (2012), pode-se considerar a existência de uma hierarquia dos níveis de mediação semiótica dos processos afetivos com diferentes níveis de generalidade. Os fenômenos da afetividade “[...] estão organizados em diferentes níveis, desde aqueles situados próximos aos processos fisiológicos imediatos, até os hiperabstratos e supergeneralizados dos sentimentos totais". (Valsiner, 2012, p. 260) No nível mais alto de generalização, os sentimentos mediados por signos são indiferenciados. Nesse sentido, “a pessoa 'simplesmente sente' algo, mas não consegue colocar tal sentimento em palavras”. (Valsiner, 2012, p. 261) Trata-se de um sentimento hipergeneralizado, semioticamente mediado, ao qual o discurso racional sobre as emoções está subordinado. Um exemplo de fenômeno afetivo de ordem superior são os valores, entendidos como "[...] recursos humanos básicos de orientação afetiva ontogeneticamente internalizados; porém, sua externalização pode ser observada em diversos aspectos da conduta humana [...] [São] campos semióticos dinâmicos". (Valsiner, 2012, p. 262) Na medida em que os valores alcançam a condição de hipergeneralizados, eles não podem mais ser facilmente verbalizados. Apesar disso, as pessoas podem agir de modo decisivo, direcionadas por seus valores. O tornar-se mãe, deste modo, pode ser considerado um valor, internalizado ao longo da trajetória de vida e intensificado ou despertado pela experiência de uma perda gestacional.

Os campos afetivos do tipo superior regulam a experiência em sua totalidade. E, uma vez que um signo do tipo campo, de caráter afetivo, se torne hipergeneralizado, ele "colore" cada nova experiência de uma pessoa. Conforme Valsiner (2012, p. 262), "[...] um fluxo de sentimento generalizado assume a direção do mundo intrapsicológico desta pessoa, começa a controlar as suas ações concretas e a enfraquecer qualquer esforço em contrário". 
Assim, ao longo da trajetória reprodutiva de Beatriz, houve a emergência de um sentimento avassalador: sentir outra vida desenvolver-se e manifestar-se dentro de si. Sentir no próprio corpo o sagrado da maternidade. Tal sentimento parece indicar que o campo afetivo tornou-se indiferenciado - resultado da abstração extensiva das emoções e de sua supergeneralização, para sentimentos gerais: “...sentir aquele ser dentro da gente, aquela movimentação, não sei, eu fiquei com vontade de sentir isso de novo". Deste modo, conforme ilustra a Figura 18, os campos de afeto ligados à maternidade cresceram, tornaram-se mais amplos e passaram a abranger campos hipergeneralizados. Por sua vez, os campos de afeto ligados à morte se afunilaram em direção ao estado do tipo ponto, exemplificado pela categoria de emoção específica denominada "pavor". Uma emoção que, apesar de intensa, tornou-se circunscrita, acessível à verbalização e à cognição.

Assim, o sagrado da maternidade - sentido nas entranhas do seu próprio corpo - funciona como um signo promotor. Um signo abstrato, que funciona como um guia de toda a gama de construções possíveis no futuro. (Valsiner, 2012) Mas, além desse poderoso signo promotor, outros signos revelam-se em operação - que denominaremos neste trabalho de signos reparadores (analisados mais detidamente no próximo capítulo). Isto é, são signos construídos no momento presente, que reparam a ruptura precipitada no passado e orientam a pessoa em direção ao futuro. No caso Beatriz, bem como em alguns dos outros casos analisados ao longo deste trabalho, os signos reparadores foram extraídos da esfera médica, como por exemplo, o signo "tratamento médico especializado". Afinal, esse signo ofereceu um significado para as perdas gestacionais experienciadas no passado - ou seja, as perdas ocorreram, pois Beatriz não teve acesso ao tratamento médico especializado; assim como para as trajetórias potenciais a serem experienciadas no futuro - quando tiver acesso a esse tratamento, não ocorrerão mais perdas gestacionais; a morte não se sobressairá à vida, mas a vida dominará a morte. E enfim, conseguirá alcançar a experiência idealizada da maternidade - do sagrado da maternidade -, que a orienta para o futuro. 
Figura 18 - Processo de generalização e hipergeneralização na regulação afetiva do fluxo da experiência

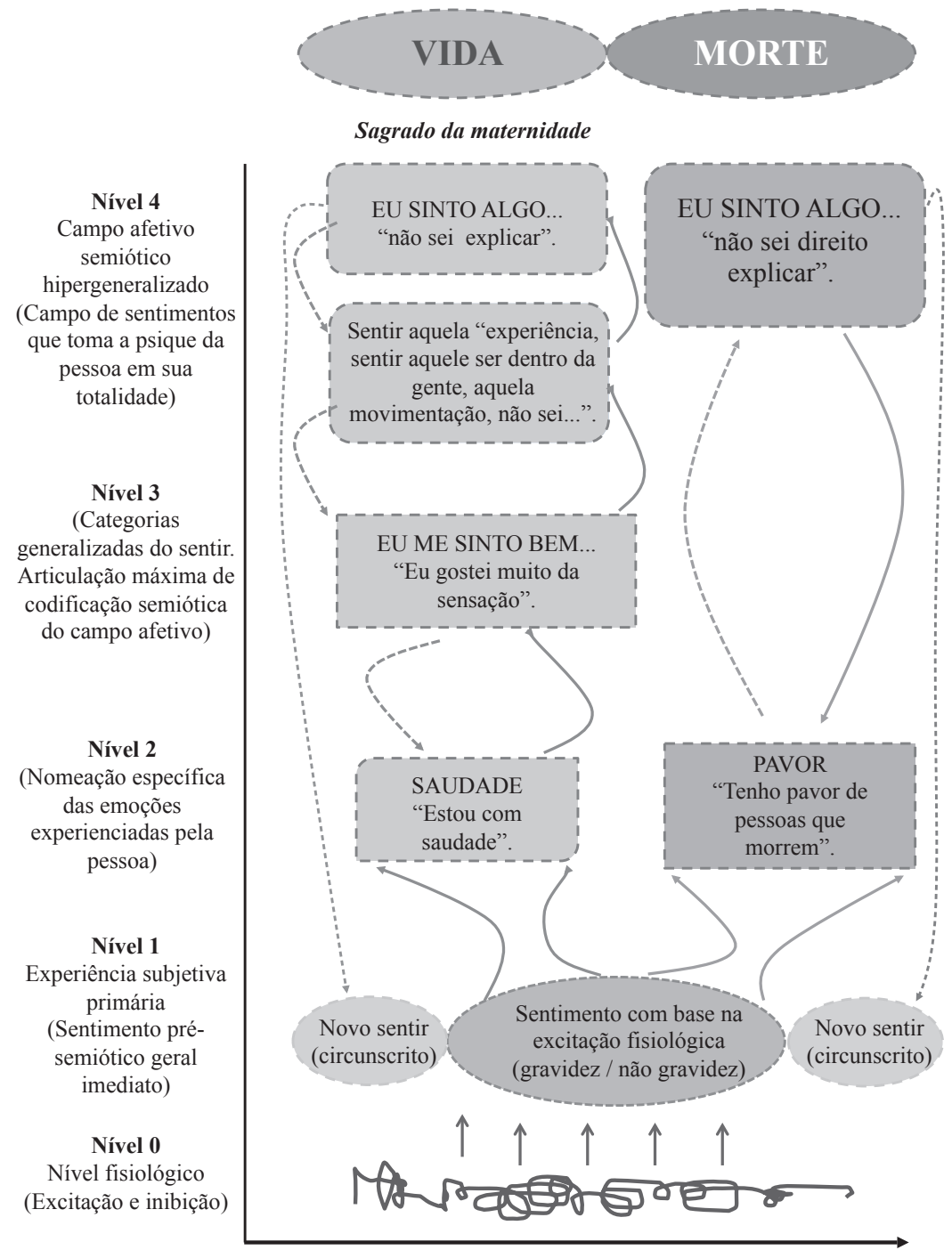

Fonte: elaboração da autora.

A Figura 19 ilustra os principais aspectos analisados da trajetória reprodutiva de Beatriz, com ênfase para as estratégias semióticas para a construção de continuidade e manutenção da posição Eu-mãe após a terceira perda gestacional. 


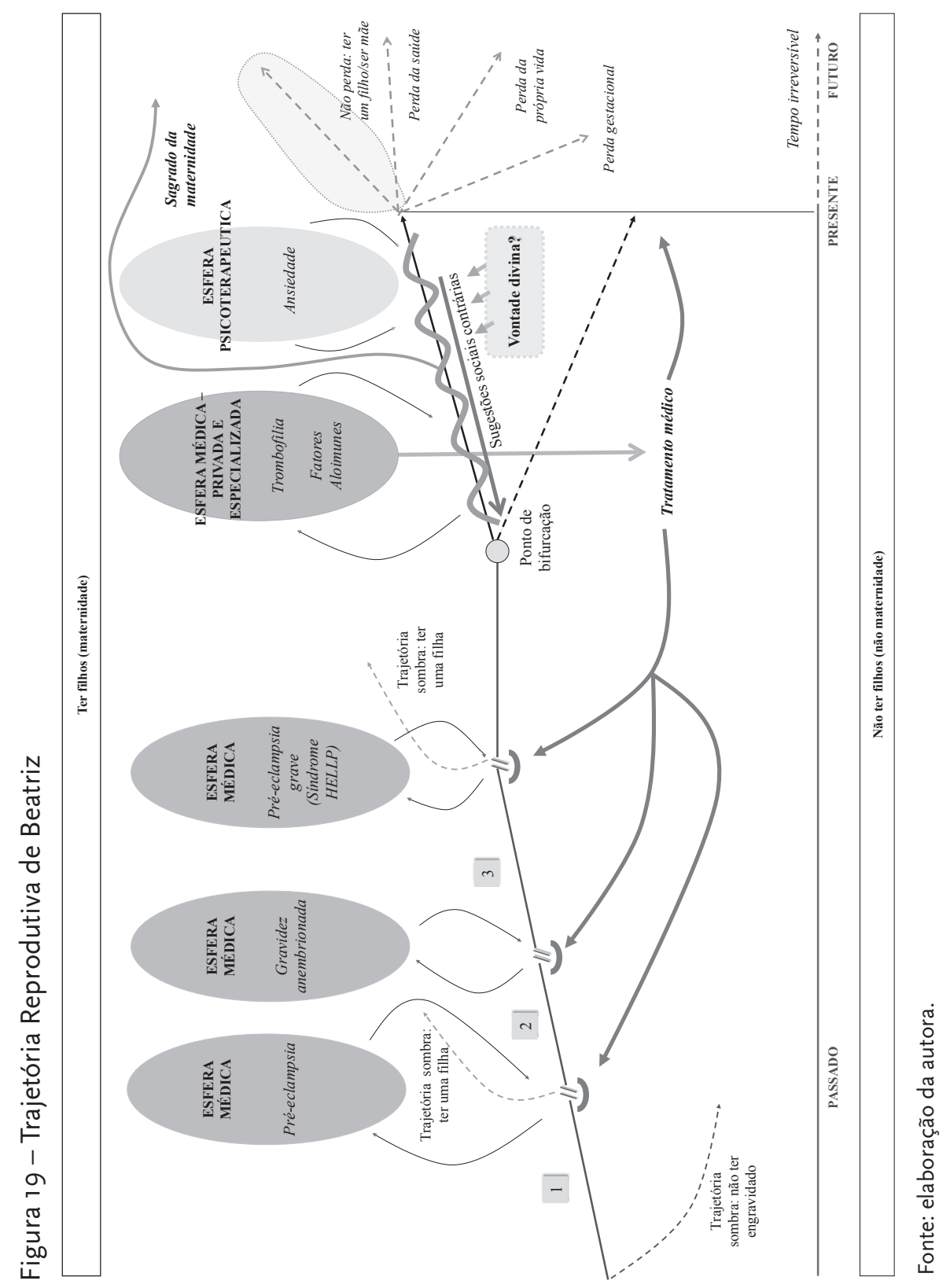

